Research, part of a Special Feature on Navigating Trade-offs: Working for Conservation and Development Outcomes

\title{
Interactive Land-Use Planning in Indonesian Rain-Forest Landscapes: Reconnecting Plans to Practice
}

\author{
$\underline{\text { Eva Wollenberg }}^{1}$, Bruce Campbell $^{2}, \underline{\text { Edmond Dounias }}^{3}$, Petrus Gunarso $^{4}$, Moira Moeliono $^{2}$, and \\ Douglas Sheil $^{5}$
}

\begin{abstract}
Indonesia's 1999-2004 decentralization reforms created opportunities for land-use planning that reflected local conditions and local people's needs. We report on seven years of work in the District of Malinau in Indonesian Borneo that attempted to reconnect government land-use plans to local people's values, priorities, and practices. Four principles are proposed to support more interactive planning between government and local land users: Support local groups to make their local knowledge, experience, and aspirations more visible in formal land-use planning and decision making; create channels of communication, feedback, and transparency to support the adaptive capacities and accountability of district leadership and institutions; use system frameworks to understand the drivers of change and resulting scenarios and trade-offs; and link analysis and intervention across multiple levels, from the local land user to the district and national levels. We describe the application of these principles in Malinau and the resulting challenges.
\end{abstract}

Key Words: land- use planning; adaptive management; Borneo; decentralization; local knowledge; spatial planning; systems frameworks

\section{INTRODUCTION}

Although spatial plans are a central feature of forest land-use policy in Indonesia, they have had little connection to the values, priorities, and practices of local peoples, especially in remote forest areas (Murdiono 1998, Sève 1999, Jepson et al. 2002). Land-use planning in Indonesia has had a history of producing centrally driven, poorly implemented plans. Meanwhile, Indonesia's forest estate continues to be severely degraded (Jepson et al. 2002), and local communities lack development opportunities (Colfer and Resosudarmo 2002, Moeliono et al. 2007).

In this paper, we analyze efforts to make spatial planning in Indonesia's forest areas more relevant to local conditions and land users. We use the example of a land-use planning project in the District of Malinau in East Kalimantan Province,
Indonesian Borneo. The project took place from 1998 to 2005 when interest in more locally responsive government was high because of recent decentralization reforms.

The Malinau project used an alternative approach to land-use planning that draws from adaptive management, systems theory, and multistakeholder principles. Planning in this approach shifted from being a preparatory, document-focused effort to a set of decision tools and processes that enabled the exchange of information, learning, and adjustments among government and local land users and managers in pursuit of a common vision. We provide examples of how the approach was tested and explain the difficulties of institutionalizing these principles during a period of policy transition. We conclude with some views about how to overcome the problems of planning in uncertain and complex environments.

\footnotetext{
${ }^{1}$ University of Vermont, ${ }^{2}$ Center for International Forestry Research, ${ }^{3}$ CIFOR, ${ }^{4}$ Tropenbos, ${ }^{5}$ Institute of Tropical Forest Conservation
} 


\section{LAND-USE PLANNING IN INDONESIA AND MALINAU}

\section{A history of national land-use planning in Indonesia}

Rural land-use planning in Indonesia has evolved through three distinct phases that reflect more decentralized decision making: techno-rationalism, regional development, and district-driven planning.

\section{Techno-rationalism}

In 1982, a first phase of national land-use planning was initiated by the Ministry of Home Affairs through legal instructions to the Ministry of Forestry (MOF) to create Consensus-Based Forest Land Use Planning via Tata Guna Hutan Kesepakatan (TGHK) - No. 26/1982, Surat Edaran Menteri Dalam Negeri No. 522.12/4275/Agr., 1982. In 1984 MOF produced TGHK maps, usually 1:500,000, that classified forest land functions as (1) protection forest, i.e., for watershed protection; (2) conservation forest in the form of national parks and other protected areas; (3) limited production forest, in which timber harvesting needs protective measures to avoid soil erosion; (4) production forest for timber harvesting; and (5) conversion forest for conversion to agriculture, plantation crops, settlements, or other uses (Sève 1999:8). The MOF's provincial representative prepared TGHK maps for each province (Jepson 2002). Much of the designation was done with little regard for conditions on the ground.

A subsequent national mapping effort, the 19871990 Regional Physical Planning Project for Transmigration (RePPProT), which was a project of the UK's Department for International Development (then the Overseas Development Administration), aimed for more reliable planning information. The project produced maps that rationalized existing TGHK maps with newly proposed land-use zones, including databases on development and reforestation areas. Despite ongoing inaccuracies, the resulting "consensus TGHK" maps $(1: 250,000)$ became the country's standard and most often used base maps (Jepson et al. 2002). In the early 1990s, the Second Land Resources Evaluation and Planning furthered these efforts by producing digitized maps.

\section{Regional development}

A second phase of land-use planning began with Indonesia's basic law of spatial planning, Act No. 24/1992, and the new involvement of the National Development Planning Board. This phase initiated the integration of land allocation with intersectoral development planning. The 1992 law decentralized spatial planning to the provincial, and later, district planning boards.

Starting in 1997, MOF was to produce new "integrated maps" or peta paduserasai that rationalized the TGHK maps with the spatial plans of the new provincial and district planning agencies. These plans were known as Rencana Tata Ruang Wilayah Propinsi/Kabupaten or RTRWP/B (Sève 1999, Jepson et al. 2002). The RTRWP/B were to include administrative boundaries, land characteristics, potential resources, and development opportunities related to diverse sectors (Auricht and Rais 2000). They aimed to coordinate and stimulate economic growth as well as plan for the efficient delivery of government services. Plans could be renewed every five years. Reflecting the pressures for wider political participation at the time in Indonesia, the law also allowed for citizen input, although in practice input was rarely solicited or offered.

The extent of decentralization in this phase was limited. Mapping was concentrated at the provincial level, and the finalization of the integrated maps was highly contentious through the 1990s. The MOF largely stalled and resisted the efforts of the planning boards, and few new plans resulted. Topdown decision making prevailed, and it was not uncommon for executive decrees at the national level to override plans (Widiangsih and Morrell 2007).

\section{District-driven planning}

A third phase of land-use planning began after the end of the Soeharto regime. Widespread reforms occurred from 1999 to 2004 that decentralized authority to elected district officials, empowered district assemblies, and channeled considerably more financial resources to district agencies. Although the RTRW framework remained intact, districts sought to create or redo their plans as a way to assert their new-found autonomy (cf. Mintzberg 1993). They rarely attempted to coordinate with 
provincial plans. The province of East Kalimantan revised its spatial plan in 1999, but it took years to be approved because of conflicts with the many new district plans. The district plans were valid for $10 \mathrm{yr}$ with evaluation after five.

Many of the old problems of centralized land-use planning persisted. Jakarta-based consulting companies prepared plans in their offices, rarely if ever making field visits, using public input, or incorporating good maps or data. Plans were photocopied from other districts. In East Kalimantan, the plans routinely permitted the use of areas protected in Indonesia's National Conservation Plan in 1981/1982 (Jepson et al. 2002). The new district planning system became a tool for legitimizing private access to district resources with little protection or concern for the public interest (Wollenberg et al. 2006b).

As before, district plans also bore little relation to what people did in the forest. In the institutional gap created during the transition to new district control, semi-autonomous local political orders emerged in which local indigenous groups, business interests, and the bureaucratic elite did their best to capture local benefits from forests regardless of existing land-use plans, legal frameworks, or central directives (McCarthy 2002, 2004, Wollenberg et al. 2006b). Districts rapidly organized small-scale timber harvesting and sought out investment schemes for conversion of natural forest to more lucrative crops.

After 2004, new national laws and regulations tried to recentralize what most people perceived as the rampant abuse of local control. Law No. 32 required district governments to coordinate their land-use planning with the provinces and the national authorities, and Regulation 26 in 2008 gave provincial governors and national ministers the right to override land-use decisions made by the districts. Indonesia continues, however, to lack a coherent government apparatus that can work across multiple administrative levels and sectors and use transparent means to resolve conflicts (McCarthy 2004).

This last and most recent phase created a window of opportunity for more locally relevant land-use planning that could better link district government spatial planning to the knowledge, experience, and aspirations of local people. It can be called the postdecentralization phase or "district planning for local economic development."

\section{Limits of planning in Indonesia}

Spatial plans in forest areas are still poorly designed and implemented. Their quality has been compromised by a history of centralized sectorbased planning, a lack of information about existing forest and land characteristics, and weak stakeholder input (Sève 1999). Implementation of spatial plans has been hampered by a number of factors, including (1) inaccurate and inconsistent maps produced under various spatial planning policies; (2) poor coordination of the Ministry of Forestry with other ministries (Sève 1999, Jepson et al. 2002); (3) poor coordination among district, provincial, and central bodies; (4) presidential decrees that took precedence over existing plans (Widiangsih and Morrell 2007); (5) a lack of local government capacity or will; (6) vested political and business interests (McCarthy 2002); (7) a lack of financial resources (Murdiono 1998); or (8) simply the unavailability of the plan (Murdiono 1998, Auricht and Rais 2000).

Although Indonesia's forest land-use plans are intended to support development goals, few address the local drivers of development or anticipate future circumstances. Information about the plans is rarely shared with other stakeholders, and the 5- to 10-yr plans are usually revised only to meet the needs of special interests. Such reliance on prescriptive longterm plans leaves little room for discretionary decision making and flexibility (Lloyd and Peel 2007). Plans under these conditions establish predetermined spatial arrangements and outcomes that serve the purposes of accountability and bureaucratic control, although they quickly become irrelevant when prescriptions are not possible or desirable, especially in situations in which political regimes are unstable, policies are in transition, natural environments change, or high levels of innovation are needed. Even as tools for accountability and control, their use is limited because they quickly lose any claim to relevance. Local land users feel no ownership of these plans, and their rights are often ignored.

Conventional planning in such contexts gives government and land-use managers a false sense of control that can lead to unanticipated outcomes and inattentiveness to critical threats or opportunities. The emphasis on plans skews attention away from real opportunities for local action. As a result, strategic decisions are often made outside of formal plans (Stacey 2003), because decisions have to be made incrementally, not all at once. 


\section{District of Malinau}

Malinau was created in 1999 when the previous district of Bulungan was divided into three new districts. The district is $42,000 \mathrm{~km}^{2}$ in size, and about $60 \%$ of its 50,000 residents are concentrated in the district capital. The 15,000-20,000 people living in the forested parts of Malinau are primarily Dayak swidden cultivators and Punan hunter-gatherers who rely on forests for their livelihoods and live in settlements of 30-1000 individuals (Sellato 2001, Sheil et al. 2006). Swidden cultivation and smallscale timber harvesting occur in localized areas throughout the district, and there are two small coal mines.

The district is $90 \%$ forest and contains the largest remaining contiguous area of Dipterocarp forest in the world. Forest land formally belongs to the state. Timber concessions allocated through Jakarta under past governments control rights to timber, although district governments have challenged these rights by allocating their own permits for timber harvesting and by changing land-use plans. The district includes most of the 1.6 million-ha Kayan Mentarang National Park, one of 80 major ecosystem reserves identified in the first national Biodiversity Action Plan and RePPProT 2002 (Jepson 2002 et al.) and has high conservation value for plants and animals (Meijaard and Nijman 2003, Sheil et al. 2006). Annual rainfall is nearly 4000 $\mathrm{mm}$, and the general erosion risk is high (Basuki and Sheil 2005).

The Center for International Forestry Research (CIFOR) began working in Malinau in 1995 and in 1998 initiated a multistakeholder land-use planning project with the Indonesian Ministry of Forestry and the district of Malinau. The aim of the project was to integrate information across different land uses and users to produce a more dynamic systems approach to land-use planning. An interdisciplinary team of about six researchers led the effort, which focused on the Malinau and Tubu watersheds. The project paid special attention to local swidden farmers and hunter-gathers, because these were groups that had been systematically excluded from prior land-use planning.

Despite intentions and efforts to do otherwise, the project operated independently from the district's own land-use planning process. Malinau developed its own district land-use plan in 2002. A Jakartabased consultant prepared maps based on information from the previous district of Bulungan, with little or no public participation and no field visits. CIFOR provided extensive ecological, forest, and social data, but the final plan showed no evidence that these data had been incorporated. The consultants presented the plan at a public hearing in the district capital that included officials and CIFOR invitees, but no village representatives from Malinau's forested areas.

During subsequent closed negotiations in 2003, the district increased the amount of conversion forest by nearly 600,000 ha and decreased reserves and limited production forest to make land available for oil palm development and increase their control visà-vis the national government over land and timber revenues (Andrianto 2006). This decision was made in spite of technical suitability measures that indicating the land should remain under forest cover. After several rounds of minor revisions, the plans were finally adopted and legalized in 2003.

The district did not make the final plan public. Our project team's efforts to see a copy of the plan were always rebuffed. Secrecy helped the district to accommodate investors without public scrutiny. In 2004 a new investor requested a block of land for an oil palm plantation. The land included part of an existing timber concession and forest in which conversion was not permitted. The district reportedly reduced the concession of the parastatal company Inhutani II from 48,000 ha to less than 28,000 ha in the land-use plan. In February 2005, Malinau submitted the revision to the Minister of Forestry for approval, but it was refused. The local government signed the memorandum of understanding with the investor anyway. The provincial government later accommodated the conversion request in its 10-yr plan, but in 2006 the Minister of Forestry rejected the province's plans to convert 1 million ha of forest to oil palm.

The resulting content of the plan was as disappointing as the process. The plan emphasized forest conversion and plantation development that would require intensive soil inputs and erosion control and decrease local people's control over land and livelihoods. It did not recognize the appropriateness of maintaining forest cover for the area or make provisions for sustainable forestry (Meijaard et al. 2005). Based on an analysis of 600 soil samples and 200 site characterizations using land and soil criteria developed by the Indonesian Department of Agriculture, Basuki and Sheil (2005) 
found that all 200 sites were marginal for the production of cash crops like pepper, coffee, rubber, or oil palm. The best sites for plantations were the alluvial plains along rivers in which local people already lived and cultivated their crops. The plan did not recognize that existing cultivation systems were sustainable only because the local people used small amounts of land, chose the best sites, maintained vegetative cover, had established long fallow periods, and rarely cultivated the same crop or field two years consecutively (E. Dounias and G. Loutrel, unpublished manuscript).

\section{AN ALTERNATIVE PLANNING APPROACH: INTERACTIVE LAND-USE PLANNING}

How can the government plan land use in Indonesia's forest areas to more effectively take into account local land capacities, the priorities of local land users, and changing conditions? On the one hand, Indonesia's existing planning frameworks produce clear rules that signal obligations and interests in efficient, transparent language that serve the formal needs of the state and citizens. On the other, the complexity of managing Indonesia's forest lands demands practical local knowledge, discretionary decision making, social processes, and adaptation (Rose 1994).

District land-use planning should link and balance these two approaches to provide not just a set of designations and control points but also an opportunity to refine and adapt decisions at larger scales based on practical experience and communication among different groups. Decision makers and citizens still need the ordered and simplified rules of a formal plan, but as part of a process that better reflects the real evolving local conditions and uncertainties that land users and managers face. A plan thus becomes only a small part of what a land-use planning team should be doing.

To achieve these aims, the project tested an alternative approach to land-use planning that draws from adaptive management, multistakeholder principles, and systems theory. This approach emerged from independent research subprojects carried out by CIFOR researchers in areas such as multidisciplinary landscape assessment, local governance and adaptive co-management, Punan health and livelihoods, integrated natural resource management, and multistakeholder land-use planning, and from the collective efforts of the Malinau team to create an integrated approach to landscape-level governance and land-use planning. We developed and refined a number of principles during the course of the project. In the end, the project produced four principles to inform the alternate approach:

1. Support local groups to make their local knowledge, experience, and aspirations more visible to formal land-use planning and decision making. Local information is costly to attain, coordinate, and use, and local groups are often not accustomed to communicating information needed for planning. Nevertheless, local-level information is essential for local needs and conditions to be acknowledged in planning, as well as for local land users to feel ownership. Clarity about tenure and rights is fundamental to understanding who should have input into land-use plans.

2. Create channels of communication, feedback, and transparency to support the adaptive capacities and accountability of district leadership and institutions. Open and multiple channels of communication and a commitment to transparency allow people to challenge, debate, and exchange information about the appropriateness of plans and when and how to adjust them. Leadership must be ready to take advantage of opportunities, quickly recognize threats, and balance tradeoffs. Public input and review should occur with adequate advance notice and funding from the district. Civil society and other government members should have access to documents, and proposed and final plans should be available in easy-to-read formats.

3. Understand the drivers of change and the scenarios associated with different land-use options, including trade-offs among objectives, using system frameworks. Whereas land-use plans may be appropriate at the time they are produced, in regions of uncertainty and rapid change plans can quickly be overtaken by new circumstances. Understanding possible trajectories of change from a systems perspective makes decision makers more attentive to what kinds of changes might occur and how to cope with them (Prato 
2007). Systems-based tools can incorporate local practical knowledge as well as represent changes in simple ways to complement maps.

4. Link analysis and intervention across multiple levels, from the local land user to the district and national levels. Land-use planning inevitably leads to a focus on a particular scale of analysis. In Malinau this is the district level, but what happens at this level is partially determined by land-use decisions made at lower levels and influenced by decisions at provincial and national levels. Thus, multiple levels of analysis and intervention and efforts to explicitly link these different levels are necessary (Sayer and Campbell 2004). District planners need to hold planning activities in villages, harness the frames of reference and perspectives of stakeholders at other levels, lobby at higher levels, and enable people from different levels to work out agreements together.

\section{THE FOUR PRINCIPLES APPLIED}

In this section we explain how the project applied the four principles from 1998 to 2005.

\section{Principle 1: Support local groups to make their local knowledge, experience, and aspirations more visible to formal land-use planning and decision making}

In Malinau, as in most forest areas of Indonesia, the voice of local Dayak and Punan villagers was rarely heard in district land-use planning (Sève 1999). CIFOR concentrated its effort on enabling these villagers to express their knowledge, experience, and aspirations. Villagers had the most to lose from district plans, because their livelihoods depended directly on agriculture and forest resources. Their ability to coordinate information and influence district policy was compromised by the huge distances between settlements and by ethnic divisions.

Villagers were also the groups most interested in working with CIFOR. The local small timber industries and mining companies were the least interested; they viewed land-use planning as a threat to their operations. Although district officials from different departments showed interest, they often needed permission to participate, were called away to district business at the last minute, or shifted roles, making it difficult to invest in building relationships with them.

Given the intense and volatile competition for forest claims during the decentralization transition (19992000), we focused most of our efforts on supporting villagers' claims to land and forest resources. We helped make those claims visible mainly through maps and research on village land uses and values. A team facilitated participatory mapping of village boundaries in 2000 for 21 villages in the Malinau watershed (Anau et al. 2001). Although these maps were an imperfect solution and by themselves did not capture the entitlements, they were probably the most important practical tool the project produced that villages could use to communicate their needs to government and timber companies. The maps could also be readily shared with formal planners and integrated into their maps.

Our research further showed that the villagers' use of forest resources extended beyond village areas and was more fluid than village boundaries would suggest. For hunting and gathering, individuals used their social networks to access a vast and fluid network of sites and forest trails that could not be easily mapped (Fig. 1). The social networks were determined by interethnic and intervillage relationships and subject to change. Any allocation of formal rights had to recognize these fluid and socially embedded informal rights and allow people the flexibility they needed to exercise them.

Local people's perceptions of the landscape and the significance and value they assigned to the geographic locations of different sites and services were important to demonstrate why villagers claimed these lands and wanted to use them in particular ways (e.g., Cunliffe et al. 2006, Lynam et al. 2006, Sheil et al. 2006). For example, local people highly valued old village sites and fruit orchards and wanted them protected against logging and other damage. Old village sites not only had heritage value but were also abundant in fruit species, making fruits such as durian (Durio spp.), coconuts (Cocos nucifera), Artocarpus spp., and mangos (Mangifera spp.) relatively plentiful. These fruits in turn attracted significant attention from frugivores, which the local people enjoyed hunting. People also valued the limestone outcrops and caves 
Fig. 1. Schematic view of sites and forest trails across two villages.

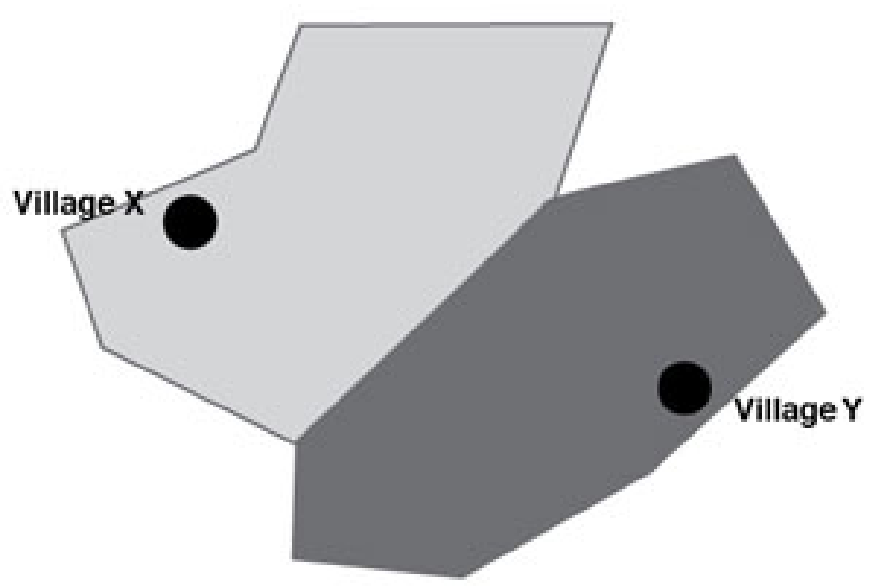

A

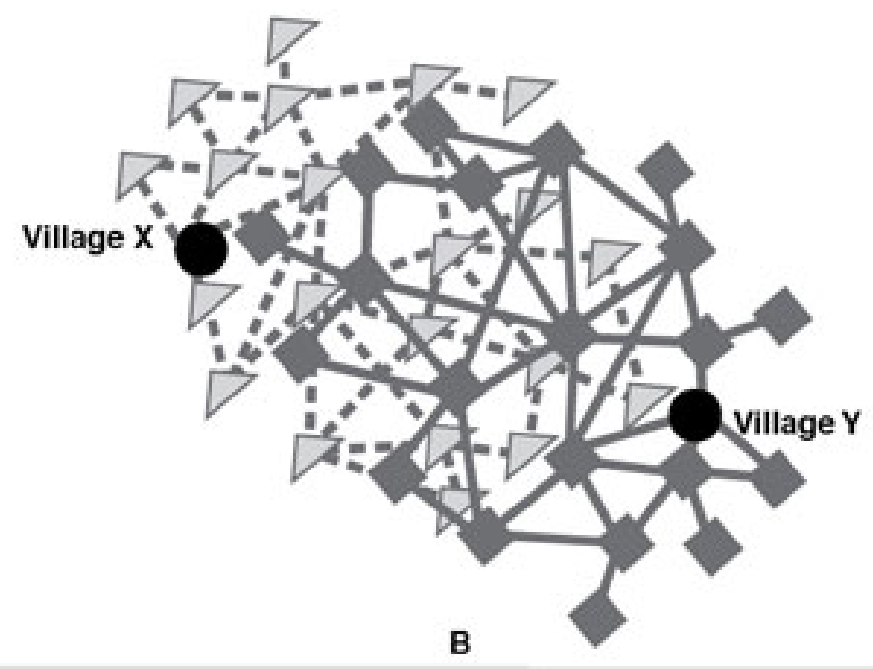

that are the home of swiftlets (mostly Collocalia spp.), whose nests have considerable cultural and commercial significance, and wanted to establish protected areas around them, as in the $1-\mathrm{km}$ exclusion zones in Malinau.

Officials undervalued local people's reliance on swidden agriculture and made little effort to accommodate it in land-use plans, other than to allocate 1 ha of land per family for permanent agriculture within village boundaries. A study of farmers in Malinau's Tubu watershed showed that choices about the location of the swidden and the type of forest used varied dramatically from year to year (Fig. 2). Fluctuations depended on the composition and availability of household labor, the farmers' health status, ever-changing partnerships and alliances among households, and the balance among agriculture and hunting, fishing, and gathering at any one time (Fig. 3). In 1994 and 2002, when there was mast fruiting and large numbers of wild bearded pigs in the area, farmers created swiddens from young fallows near the villages, rather than investing in clearing older forests for more productive land. In contrast, in years like 1989 and 1998-2000, they made massive clearings in distant primary forest or very old fallows. The severe interannual fluctuations of fruiting and bearded pig populations in Dipterocarp forests accordingly affect the strategies of forest dwellers and influence how land is used. Assessing the land needed in 1994 would have led to a detrimental underestimation of the land cover they actually need to practice swidden agriculture.

\section{Principle 2: Create channels of communication, feedback, and transparency to support the adaptive capacities and accountability of district leadership and institutions}

The research team also worked to bridge the gaps between groups so that they could communicate their values and practices directly to one another and participate in all decisions that affected them. We did this by facilitating meetings among groups who did not ordinarily meet with one another, documenting and disseminating stakeholders' views, monitoring land use and social conditions, and supporting awareness of good governance measures. Such communication and involvement were essential so that decision makers could integrate information from different sources and at different scales as they adapted to changing conditions.

Multistakeholder forums addressed forest policy issues at the community, district, and provincial levels. They included annual meetings with all the 
Fig. 2. Percentages of land under different stages of fallow in Tubu villages in 2003.
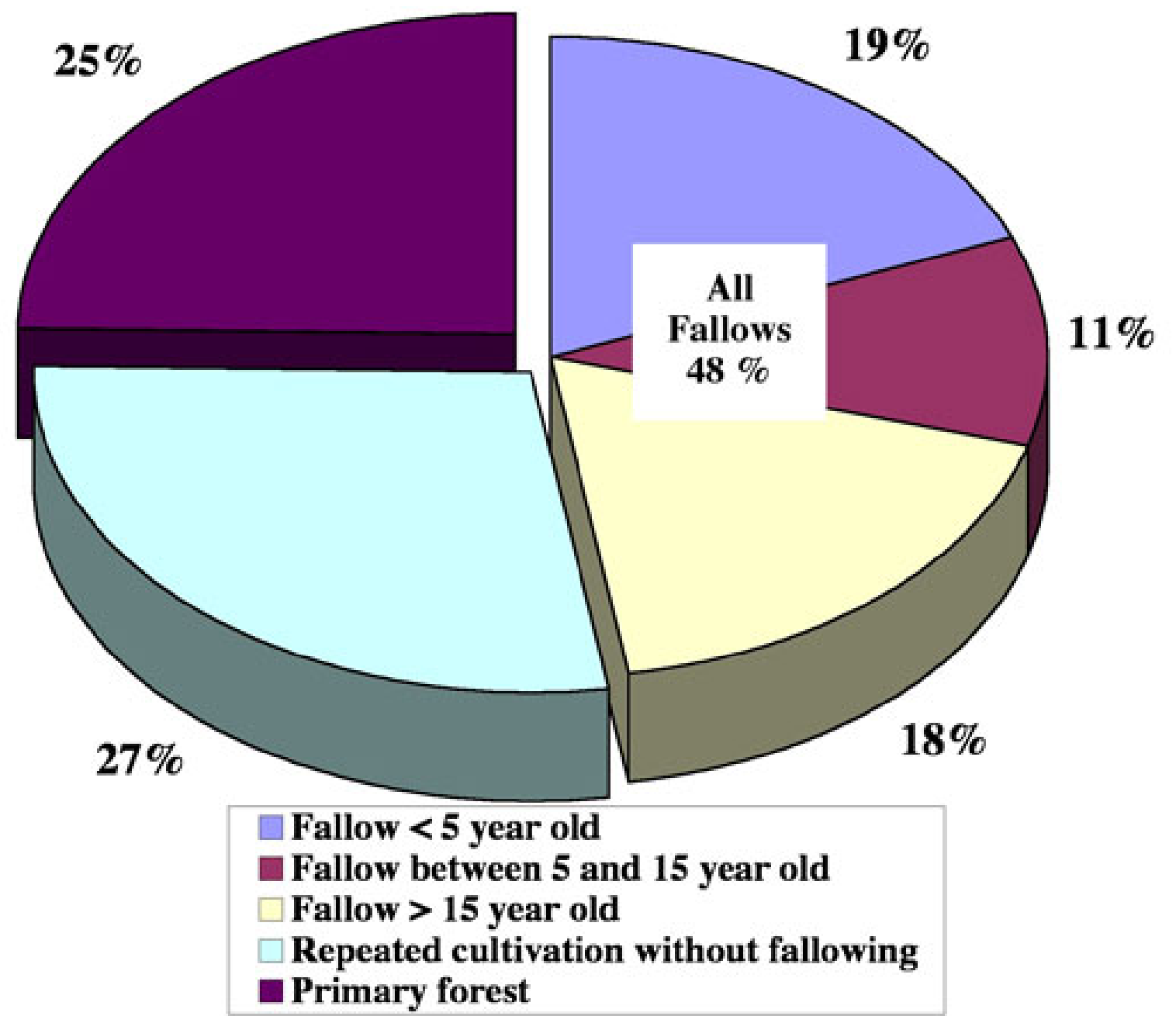

villages in the Malinau watershed, to which government officials were invited and at which a community-government dialogue was held. The CIFOR team also arranged for government officials to attend village activities and for villagers to visit district officials. These events were generally well attended and successful in creating opportunities for dialogue. Participants saw them as opportunities for getting new information.

Team members monitored forest and social conditions at the village level from 2000 to 2005 , providing data and analysis three to five times each year to both villagers and government officials that helped to document the rapid changes in forest use occurring at the time. This information was critical to building awareness in the district about the rapidity and extent of changes occurring during the reform era.

Researchers also collected the views of different stakeholders about desirable governance in Malinau in terms of representation, accountability, land-use planning, agreements, sharing forest benefits, conflict management, and sharing of information (Wollenberg et al. 2006a). Although district officials and villagers agreed that communities should provide input on land-use planning, the 
Fig. 3. Annual variation in area of cultivated land in Tubu villages.

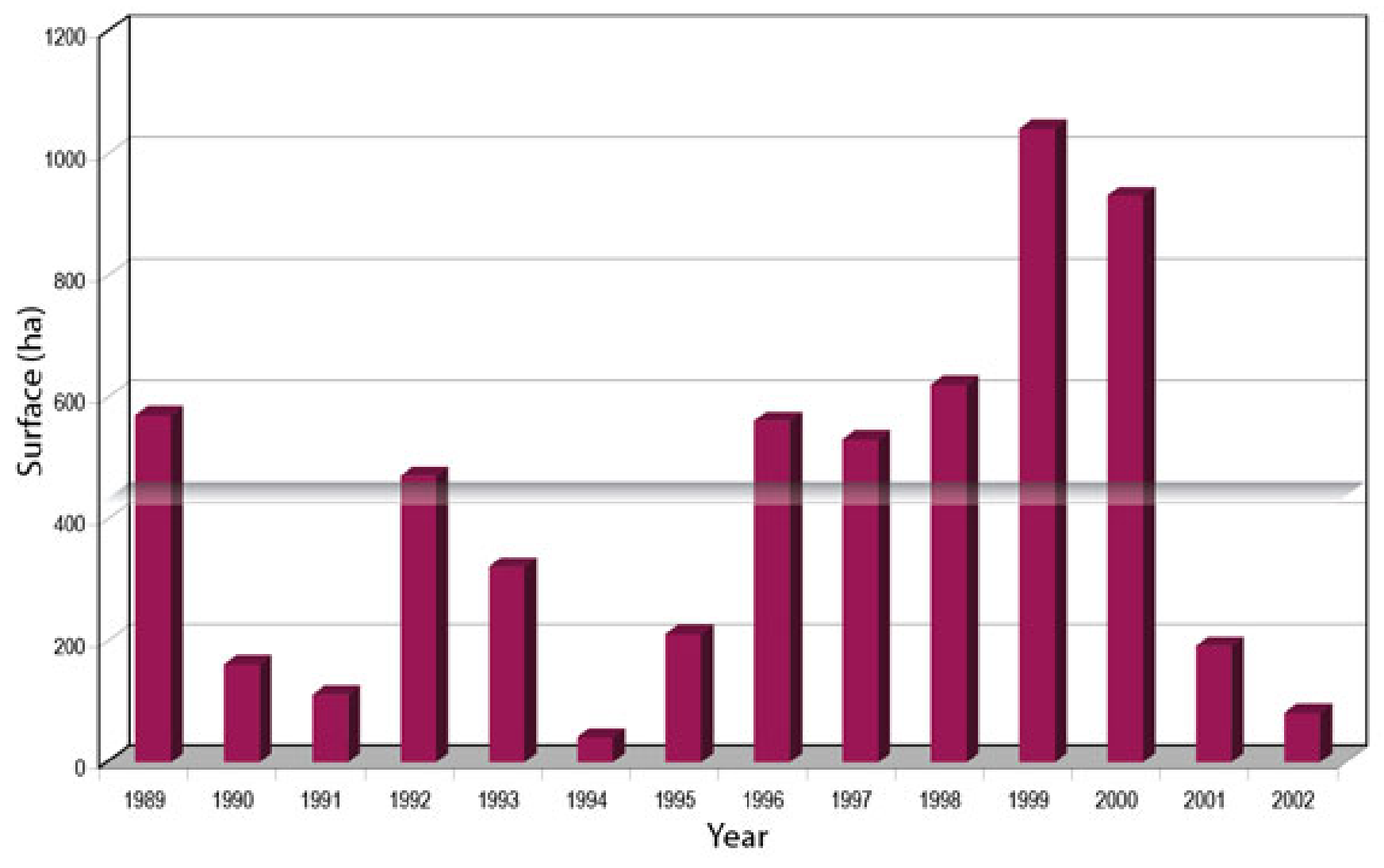

research showed that there was considerable variation in people's expectations about forest governance and only a limited capacity to practice many of these principles. Communication and accountability were often limited in Malinau by topdown and clientelist governance.

\section{Principle 3: Understand the drivers of change and scenarios associated with different land- use options, including trade-offs among objectives, using system frameworks}

CIFOR researchers assisted stakeholders in Malinau to explore potential changes, trends, and trade-offs through social processes as well as simulation modeling. To establish a shared foundation for the planning process, one of our first activities was a multistakeholder workshop to collectively identify the parameters of Malinau's land-use system and develop a shared vision for land use based on scenario visioning tools (Wollenberg et al. 2000). The group identified the drivers of change they experienced under decentralization, $i$. e., increased small-scale timber harvesting, increased funds for local development, empowered local citizens, and their collective objectives for the future, which included (1) increased income; (2) clear land use according to rights and land-use functions; (3) the development of organizations that are efficient, coordinated, and transparent; and (4) environmental conservation.

This information was used as input for simulation modeling to project the Malinau landscape and economy for $20 \mathrm{yr}$. The model was designed to stimulate debate about the future rather than be a predictive tool (Sandker et al. 2007, 2008, Campbell et al. 2009). The model could incorporate practical knowledge generated by different groups and allow 
people to discuss risks and wider concerns and motivations for different kinds of land use, e.g., heritage, gravesites, conservation. Likely drivers of change were included in the model, making it possible to explore diverse scenarios and conduct policy experiments. The model was built together with the planners at the district level, giving them a degree of ownership of the model. In one of the closing workshops for the project, district officials presented the results of different model scenarios to their colleagues. The models highlighted the tradeoffs of different development trajectories. For example, a high investment scenario of plantation development brought major development outcomes for the district, but these came at the cost of biodiversity conservation and the likely marginalization of the current land users.

\section{Principle 4: Link analysis and intervention across multiple levels}

The project worked at the district, subdistrict, watershed, village, household, individual, and forest site levels. Analysis and intervention at these multiple levels were essential to understanding land-use patterns at different scales and the motivations or drivers behind them. For example, the impacts of large land-use initiatives such as oil palm or timber plantations often spanned across villages and needed to be understood in terms of their relation to village land claims and household use of forest resources as well as for their impacts on specific forest sites and watersheds.

We supported coordination of land-use planning among villages in the Malinau watershed in which small-scale timber extraction was most rampant through the production of village plans and annual meetings. We facilitated the production of scenarios of preferred village land uses, as well as supporting maps, inventories, and management plans. Villages discussed alternatives and documented what existed. One village used the maps to identify their core conservation area and different land-use zones. Another designated areas for timber exploitation, protection, and subsistence use. We worked with the surrounding two or three villages to manage conflicts over land and create similar opportunities for land-use planning. As a result, the area of conserved forest nearly doubled when a neighboring village also allocated land for conservation.

To scale up village efforts to the district level, we invited land-use planners and government officials to participate in public village meetings and encouraged the district to communicate to the villagers what was feasible from the district's perspective. Villagers were encouraged to make presentations to district officials about their plans. The project lobbied the provincial and national authorities to recognize these community efforts, for which one village received a national environmental prize and was a finalist for the international World Water Prize.

Researchers shared the results of all studies with the communities and other local stakeholders to make the analysis available to them and deepen their general understanding. Products took the form of hundreds of newsletters, 3500 posters, 6000 information-rich cards, and several hundred copies of videos. In addition, researchers collaborated with local government and the World Wildlife Fund to develop an environmental education syllabus for Malinau's schools (Padmanaba and Sheil 2006).

\section{DISCUSSION}

The experience in Malinau reflected the historical context of the postdecentralization and districtdriven land-use planning period. Dayak and Punan villagers gained more awareness, provided more input, and negotiated harder for their land-use priorities than had been possible during previous decades (Wollenberg et al. 2007). Land-use planning reached heightened levels of political accountability and participation. Rigorously collected local data were organized in GIS models and applied in spatial modeling.

Despite the richness of these developments, the district produced a conventional land-use plan and subsequent land-use decisions that departed from that plan. Decisions lacked relevance to Malinau's land capabilities and the existing land-use practices of the local people. Instead, these decisions served the interests of district officials in incomegenerating projects, which they justified with narratives about "economic development" and "modernization." They also helped maintain political capital among the district's entrepreneurs and selected village leaders who also benefited from the schemes. The politics of land use, driven by the possibilities for economic gain, thus took precedence over technical planning considerations.

Politics prevailed in previous eras as well, only this time the politics that mattered most were at the 
district level, and many government officials and entrepreneurs were themselves local people and even indigenous leaders (cf. McCarthy 2004, Wollenberg et al. 2005). Indonesia's political traditions of hierarchical decision making, paternalism, secrecy, and local clientelism enabled officials to fall back on old-style decision making. As Hudalah and Woltjer (2007) point out, these forces point to a basic tension inherent in Indonesian land-use planning between introduced western models of planning and the existing decisionmaking culture. Officials pay attention to formal planning at a token superficial level, yet fall back on more comfortable and binding social norms when conflicts among interests occur. As districts experimented with other participatory, democratic approaches such as public consultations and accountability reports during this period, there were similar tensions and efforts to shift between the more accountable measures and old political habits. Officials and citizens appeared to be trying the new methods out like new outfits, not always sure what would fit and sometimes preferring their old favorites.

Ironically, in this way, land-use planning in the postdecentralization period was more localized and adaptive, but the related decisions were not transparent, clearly in the public interest, or scientifically based. They gave primacy to the interests of a few at the district level, compromising the land-use priorities of multiple local land users and national bodies. Relocating land-use planning to local levels and using adaptive decision making are therefore not enough to ensure more interactive land-use planning. Although empowerment of local communities has been a powerful force for change, as our experience shows, it may not be enough to sufficiently democratize land-use decisions and change relative power relations if the forces in power do not need or have any incentive to change (Garnett et al. 2007).

To make planning more relevant in places like Malinau, we need to shift our thinking about planning away from planning as an instrument of control to one of innovation and action (Byrne 2003:171). Byrne says that we need to work with people in a participatory way to specify the range of possible futures and establish actions that will produce the futures people want. Facilitation and intervention according to the principles in this article can help. In Malinau the four principles presented here gave villagers and officials the tools they needed to tackle the entrenched political culture and work in parallel to it. Although the results did not change the entire system, they did increase awareness of alternatives and balance tensions with old political traditions. Villagers developed higher expectations of local governance (Wollenberg et al. 2006a), officials gained more awareness of local priorities, and some villages more actively resisted pressures for logging (Iwan 2004).

The project highlighted conflicts associated with (1) the district's aim to generate income through largescale extractive projects; (2) conservation priorities for species and area protection that differed among local people and national and international bodies; and (3) local people's needs for land rights and flexibility in managing their forest, swidden, and fallows to respond to variations in natural resource availability, fluctuating social networks, and their needs for flexibility of access and benefit sharing. In each case, the conflicts involved the constraining of discretionary decision making by other parties. These conflicting needs suggest that the requirement for governance measures and interactive land-use planning is much higher than most people assume, even at the local level.

The district government and communities never fully developed the leadership, will, or institutional capacity to carry out more dynamic forms of landuse planning independently. Although the concepts of adaptive management and participation were attractive, they involved skills, information, coordination, and resources that were often not available, especially in a newly formed district struggling with more immediate pressures in a chaotic policy environment. These factors may be ultimately the most important limits to implementing more dynamic forms of land-use planning (cf. Lebel et al. 2007, Prato 2007, Wollenberg et al. 2007).

Efforts to improve planning almost always focus on technical aspects, forgetting that in many places capacities do not exist to carry these out. When landuse planning enables discretionary decision making, strong governance systems for transparency and more sensitivity and capacity building among decision makers are necessary (Lloyd and Peel 2007). Capacities need to be built in both government and members of civil society, including sources such as universities or NGOs who can facilitate training and communication. 
The kind of planning we are advocating is expensive. Interactive planning should be most appropriate in places of high resource value and threat, in which the stakes are high. Conventional plans can still play a role in land-use decisions, provided that they are more adaptive, participatory, and set in larger governance frameworks. Interactive planning may benefit from external facilitation, because dynamic contexts often make it difficult for planners and managers to invest in the necessary transaction costs of participation and information exchange.

Responses to this article can be read online at: http://www.ecologyandsociety.org/voll4/iss l/art35/ responses/

\section{Acknowledgments:}

The research was supported by the International Tropical Timber Organization (IITO), the Department for International Development (DfID) UK, the Ford Foundation, the District of Malinau, and the Netherlands Committee of IUCN. We thank two anonymous reviewers for their helpful comments.

\section{LITERATURE CITED}

Anau, N., R. Iwan, M. van Heist, G. Limberg, M. Sudana, and E. Wollenberg. 2001. Pemetaan Desa Partisipatif dan Penyelesaian Konflik Batas: Studi Kasus Desa-Desa Daerah Aliran Sungai Malinau, Januari s/d Juli 2000. Center for International Forestry Research, Bogor, Indonesia.

Anau, N., R. Iwan, M. van Heist, G. Limberg, M. Sudana, and E. Wollenberg. 2002. Negotiating more than boundaries: conflict, power, and agreement building in the demarcation of village borders in Malinau. Pages 131-156 in Center for International Forestry Research. ITTO project PD 12/97 Rev.1 (F): forest, science and sustainability: the Bulungan model forest: technical report phase 1, 1997-2001. CIFOR, Bogor, Indonesia.

Andrianto, A. 2006. The role of district government in poverty alleviation: case studies in Malinau and West Kutai districts, East Kalimantan, Indonesia.
Center for International Forestry Research, Bogor, Indonesia.

Auricht, C. M., and J. Rais. 2000. Spatial development planning in Indonesia; report, Land Administration Project, part C. National Development Planning Agency and National Land Agency, Government of Indonesia, Jakarta, Indonesia.

Basuki, I., and D. Sheil. 2005. Local perspectives of forest landscapes: a preliminary evaluation of land and soils, and their importance in Malinau, East Kalimantan, Indonesia. Center for International Forestry Research, Bogor, Indonesia.

Byrne, D. 2003. Complexity theory and planning theory: a necessary encounter. Planning Theory 2 (3):171-178.

Campbell, B., J. Sayer, R. M. Cowling, H. Kassa, A. Knight., M. Sandker, and A. Suwarno. 2009. The role of participatory modeling in landscape approaches to reconcile conservation and development. Ecology and Society 14(1): in press.

Colfer, C., and I. Resosudarmo. 2002. Which way forward: people, forests and policy making in Indonesia. Resources for the Future, Washington, D.C., USA.

Cunliffe, R., T. Lynam, D. Sheil, M. Wan, A. Salim, I. Basuki, and H. Priyadi. 2006. Developing a predictive understanding of landscape importance to the Punan-Pelancau of East Kalimantan, Borneo. Ambio 36(7):593-599.

Forester, J. 1989. Planning in the face of power. University of California Press, Berkeley, California, USA.

Garnett, S. T., J. Sayer, and J. du Toit. 2007. Improving the effectiveness of interventions to balance conservation and development: a conceptual framework. Ecology and Society 12(1): 2. [online] URL: http://www.ecologyandsociety.org/ vol12/iss1/art2/.

Hudalah, D., and J. Woltjer. 2007. Spatial planning system in transitional Indonesia. International Planning Studies 12:291-303.

Iwan, R. 2004. Mobilizing community conservation: a community initiative to protect its forest against logging in Indonesia. Available online at: http://dlc. 
dlib.indiana.edu/archive/00001415/00/

Iwan Mobilizing 040524 Paper176d.pdf.

Jepson, P., F. Momberg, and H. van Noord. 2002. A review of the efficacy of the protected area system of East Kalimantan, Indonesia. Natural Areas Journal 22(1): 28-42.

[ERRATUM]

Lebel, L., J. M. Anderies, B. Campbell, C. Folke, S. Hatfield-Dodds, T. P. Hughes, and J. Wilson. 2006. Governance and the capacity to manage resilience in regional social-ecological systems. Ecology and Society 11(1):19. [online] URL: http:/ /www.ecologyandsociety.org/vol11/iss1/art19/.

Lloyd, M. G., and D. Peel. 2007. Shaping and designing model policies for land use planning. Land Use Policy 24:154-164.

Lusiana, B., M. van Noordwijk, and S. Rahayu, editors. 2005. Carbon stocks in Nunukan, East Kalimantan: a spatial monitoring and modelling approach: report from the carbon monitoring team of the Forest Resources Management for Carbon Sequestration (FORMACS) project. World Agroforestry Centre, ICRAF, Bogor, Indonesia.

Lynam, T., R. Cunliffe, D. Sheil, M. Wan, A. Salim, H. Priyadi, and I. Basuki. 2006.

Livelihoods, land types and the importance of ecosystem goods and services: developing a predictive understanding of landscape valuation by the Punan Pelancau people in East Kalimantan. Center for International Forestry Research, Bogor, Indonesia.

McCarthy, J. F. 2002. Turning in circles: district governance, illegal logging, and environmental decline in Sumatra, Indonesia. Society and Natural Resources 15:867-886.

McCarthy, J. F. 2004. Changing to gray: decentralization and the emergence of volatile socio-legal configurations in central Kalimantan, Indonesia. World Development 32:1199-1223.

Meijaard, E., and V. Nijman. 2003. Primate hotspots on Borneo: predictive value for general biodiversity and the effects of taxonomy. Conservation Biology 17:725-732.

Meijaard, E., D. Sheil, R. Nasi, D. Augeri, B.
Rosenbaum, D. Iskandar, T. Setyawati, A. Lammertink, I. Rachmatika, A. Wong, T. Soehartono, S. Stanley, and T. O'Brien. 2005. Life after logging: reconciling wildlife conservation and production forestry in Indonesian Borneo. Center for International Forestry Research, Bogor, Indonesia.

Mintzberg, H. 1993. The rise and fall of strategic planning. Free Press, New York, New York, USA.

Moeliono, M., G. Limberg, C. Goenner, E. Wollenberg, and R. Iwan. 2007. Towards wellbeing: monitoring poverty in Malinau, Indonesia. Center for International Forestry Research, Bogor, Indonesia.

Murdiono, L. W. 1998. Environmental planning In Indonesia: the linkage between spatial plan and environmental impact assessment. Thesis. Massachusetts Institute of Technology, Boston, Massachusetts, USA.

Padmanaba, M., and D. Sheil. 2006. Finding and promoting a local conservation consensus in a globally important tropical forest landscape. Biodiversity and Conservation 16(1):137-151.

Prato, T. 2007. Evaluating land use plans under uncertainty. Land Use Policy 24:165-174.

Rose, C. M. 1994. Property and persuasion: essays on the history, theory and rhetoric of ownership. Westview Press, Boulder, Colorado, USA.

Sandker, M., B. M. Campbell, and A. Suwarno. 2008. What are participatory scoping models? Ecology and Society 13(1): r2. [online] URL: http:/ /www.ecologyandsociety.org/vol13/iss 1/resp2/.

Sandker, M., A. Suwarno, and B. M. Campbell. 2007. Will forests remain in the face of oil palm expansion? Simulating change in Malinau, Indonesia. Ecology and Society 12(2): 37. [online] URL: http://www.ecologyandsociety.org/vol12/iss2/ $\underline{\operatorname{art} 37 /}$.

Sayer, J., and B. Campbell. 2004. The science of sustainable development: local livelihoods and the global environment. Cambridge University Press, Cambridge, UK.

Scott, J. 1998. Seeing like a state. Yale University Press, New Haven, Connecticut, USA. 
Sellato, B. 2001. Forest, resources and people in Bulungan: elements for a history of settlement, trade and social dynamics in Borneo, 1880-2000. Center for International Forestry Research, Bogor, Indonesia.

Sève, J. 1999. A review of forestry sector policy issues in Indonesia. Environmental Policy and Institutional Strengthening IQC OUT-PCEI-806-96-00002-00. US AID, Jakarta, Indonesia.

Sheil, D., and N. Liswanti. 2006. Scoring the importance of tropical forest landscapes with local people: patterns and insight. Environmental Management 38:126-136.

Sheil, D., R. Puri, M. Wan, I. Basuki, M. van Heist, N. Liswanti, Rukmiyati, I. Rachmatika, and I. Samsoedin. 2006. Local people's priorities for biodiversity: examples from the forests of Indonesian Borneo. Ambio 35:17-24.

Stacey, R. D. 2003. Strategic management and organisational dynamics: the challenge of complexity. Fourth edition. Financial Times/ Pearson Education, London, UK.

Theobald, D. M., N. T. Hobbs, T. Bearly, J. Zack, T. Shenk, and W. E. Riebsame. Incorporating biological information in local land use decision making: designing a system for conservation planning. Landscape Ecology 15(1):35-45.

Widianingsih, I., and E. Morrell. 2007. Participatory planning in Indonesia: seeking a new path to democracy. Policy Studies 28:1-15.

Wollenberg, E., D. Edmunds, and L. Buck. 2000. Anticipating change: scenarios as a tool for adaptive forest management; a guide. Center for International Forestry Research, Bogor, Indonesia.

Wollenberg, E., R. Iwan, G. Limberg, M. Moeliono, S. Rhee, and M. Sudana. 2007. Facilitating cooperation during times of chaos: spontaneous orders and muddling through in Malinau District, Indonesia. Ecology and Society 12(1): 3. [online] URL: http://www.ecologyandsoc iety.org/vol12/iss1/art3/.

Wollenberg, E., G. Limberg, R. Iwan, R. Rahmawati, and M. Moeliono. 2006a. Our forest, our decision.: a survey of principles for local decision-making in Malinau. Center for International
Forestry Research, Bogor, Indonesia.

Wollenberg, E., M. Moeliono, G. Limberg, R. Iwan, S. Rhee, and M. Sudana. 2006b. Between state and society: local governance of forests in Malinau, Indonesia. Forest Policy and Economics 8:421- 433.

Wollenberg, E., D. Edmunds, and L. Buck. Scenarios as a tool for adaptive management: a guide. Center for International Forestry Research, Bogor, Indonesia. 